\title{
EXPLANATIONS FOR LAW REFORM: THE CASE OF WARTIME LABOUR LEGISLATION IN BRITAIN, 1915-1916
}

Among the various theoretical insights which seek to explain the emergence (and, for our purposes, the amendment) of 'social' legislation, the interpretation advanced by Oliver MacDonagh to explain nineteenth century governmental developments is widely known. This approach, which ascribes legal changes to the 'pressure of events', is built upon a five-stage model, progressing from the 'discovery' of an 'evil', to its administrative solution by means of legislative enactment. MacDonagh's formulation attracted, in turn, the criticism of those students of nineteenth century government growth, who pointed to the influence of Benthamite ideas as the forcing-house of change. Latterly, John Goldthorpe has sought to place emphasis on the role of social movements in galvanising legal reforms, suggesting how different interest groups might vie with one another in a pluralistic struggle for success. ${ }^{1}$

Refinements to these approaches might, however, be suggested. First, legislative success might not necessarily be measured in instrumental or in economic terms but also (or alternatively) in terms of the campaign promoters' quest for enhanced prestige. Thus, success through statute might be symbolic of the claimed superiority of a particular set of values, as has been suggested, for example, in the case of the Prohibition campaign in the

1 See, respectively, O. MacDonagh, "The Nineteenth Century Revolution in Government: A Reappraisal”, Historical Journal, Vol. 1, 1958, pp. 52-67; Jenifer Hart, "Nineteenth Century Social Reform: A Tory Interpretation”, Past \& Present, No 31, 1965, pp. 39-61; and J.H. Goldthorpe, "The Development of Social Policy in England, 18001914", Transactions of the Fifth World Congress of Sociology, Vol. IV, (Washington, DC, 1962), p. 55. These approaches have all been summarized briefly in Peter W.J. Bartrip, "Public Opinion and Law Enforcement: The Ticket-of-Leave Scares in MidVictorian Britain", in Victor Bailey (ed.), Policing and Punishment in Nineteenth Century Britain (London, 1981), pp. 150-2. In his own study of a specific mid-nineteenth century penal reform, Bartrip favours a 'pressure of events' interpretation. 
United States during the 1920 s. For the participants on each side, ${ }^{2}$

Victory or defeat were [. . .] symbolic of the status and power of the cultures opposing each other. Legal affirmation or rejection is thus important in what it symbolizes as well or instead of what it controls. Even if the law is broken, it was clear whose law it was.

Moreover, a symbolic crusade might be conducted not simply to bolster claims to cultural superiority over a particular adversary, but perhaps to enable the campaigners to enjoy social rehabilitation within a particular grouping from whom they were in danger of becoming estranged, or with whom relations were deteriorating.

What we propose to explore in this paper is the applicability of these explanatory frameworks to a case study concerning the campaign to amend the Munitions of War Act 1915 in Britain. The Munitions Act of early July 1915 was the statutory measure employed by Lloyd George, the Minister of Munitions, to regulate wartime industrial relations in those industries which supplied the material sinews of war. Impatient with the trade unions' tepid compliance with a voluntary accord reached with the government three months earlier (the Treasury Agreement of March 1915), whereby the trade union leadership committed their membership to co-operative working practices with employers in order to expedite the output of munitions, Lloyd George moved rapidly to a more coercive, legally backed wartime industrial relations strategy. Moreover, by explaining his plans for legislation to selected groups of trade union leaders, he felt confident in claiming that the shift from voluntarism to regulation had the approval of the labour movement. ${ }^{3}$

It was no idle claim by the future Prime Minister given that a number of union leaders accepted the advent of a statutory code of labour regulation as the embodiment of the spirit of sacrifice. Alexander Wilkie of the Shipwrights' Association, for example, observed that. ${ }^{4}$

The Act, as we stated in the House of Commons, was a drastic one, but we

2 Joseph Gusfield, "Moral Passage: The Symbolic Process in Public Designations of Deviance", in C.A. Bersani (ed.), Crime and Delinquency (London, 1970), p. 67, cited in W.G. Carson, "Symbolic and Instrumental Dimensions of Early Factory Legislation", in R. Hood (ed.), Crime, Criminology and Public Policy: Essays in Honour of Sir Leon Radzinowicz (London, 1974), p. 111. Gusfield's principal work is Symbolic Crusade (Urbana, 1963).

${ }^{3}$ B.C. Roberts, The Trades Union Congress 1868-1921 (London, 1958), p. 278.

4 Shipconstructors' and Shipwrights' Association (SSA), Quarterly Report, July-September 1915, p. 5. For other welcoming comments, see J.R. Clynes, What is the Munitions of War Act? (London and Manchester, 1915) and references in Gerry R. Rubin, War, Law, and Labour: The Munitions Acts, State Regulation and the Unions, 1915-1921 (Oxford, 1987), Ch. One. 
have to remember that we are at war, and many things have to be done in such emergencies as would not be contemplated in peacetime.

The 'emergency' provisions included a prohibition of strikes in the munitions trades, the introduction of compulsory arbitration, the restriction on free movement of labour and the establishment of a set of workshop disciplinary rules. To enforce the provisions of the Munitions Act, a national network of munitions tribunals was established to try those charged with striking unlawfully or with infringing the disciplinary rules. Claims by workers for leaving certificates to enable them to move to other employment or for the payment of wage awards fixed by compulsory arbitration could also be heard. Employers could thus be forced to appear before the tribunals in order to resist such claims by munitions workers, while accusations of labour poaching could also be levelled by one firm against another. The labour campaign to amend the Munitions Act, to be sure, was scarcely premised on the plight of employers discomfited by having to defend themselves before the tribunals. For it was the harsh experience of munitions workers at the hands of the tribunals (or such a perception of their treatment) especially but not exclusively in Glasgow, which triggered off demands for the reform of the 1915 Act. But the transformation of individual causes for complaint into a dramatic campaign to change the law is dependant on intervening factors, the nature of which, as we have seen above, is the subject of dispute. What we would argue, in respect to the amendment of the Munitions Act, is that, taken in isolation, each element of the "causal triumvirate: ideas, movements and events's (corresponding to the Benthamite, Goldthorpe and McDonagh approaches, respectively), is deficient in providing a comprehensive explanation for the emergence of the Amendment Act in 1916. For example, it is beyond dispute that following the imprisonment of three shipwrights from Fairfield shipyard in Glasgow in October 1915, for having infringed the strike provisions of the Munitions Act, the crisis proportion of the 'pressure of events' on Clydeside, involving threats of a general strike in this crucially important munitions centre, galvanized the government into a drastic reconsideration of its legal strategy. ${ }^{6}$

Yet it was, in fact, a disparate collection of 'idealists' who set the campaign in motion. Thus, from the outset, a number of radical critics, activists

${ }_{6}^{5}$ Bartrip, op. cit., p. 150.

${ }^{6}$ The Fairfield incident has been well rehearsed in the literature. See, for example, James Hinton, The First Shop Stewards' Movement (London, 1973), pp. 116-8; C.J. Wrigley, David Lloyd George and the British Labour Movement (Hassocks, 1976), pp. 141-2; Iain S.McLean, The Legend of Red Clydeside (Edinburgh, 1983), pp. 41-2; 
and journalists, though basically resourceless or unpopular or unorganized, ${ }^{7}$ sought to propagate an alternative critical perspective to the 1915 Act to that advanced by trade union leaders such as Wilkie of the Shipwrights' Association, John Hill of the Boilermakers' Society or J.R. Clynes of the General Workers Union. Some 'idealists', such as the Guild Socialists, G.D.H. Cole and William Mellor, were also instrumental in framing specific reform proposals. ${ }^{8}$ Moreover, even Goldthorpe's concept of a 'movement' as a harbinger of change would require to be stretched to accommodate the complexity of the situation. For though the 'pressure of events' seemed to give rise, in its turn, to a genuine mass-movement united under the banner of reform, the evidence indicates that the 'movement' was less solid and persuasive than appearances might suggest. For one in-

Alastair Reid, "Dilution, trade unionism and the state in Britain during the First World War", in Steven Tolliday and Jonathan Zeitlin (eds.), Shop Floor Bargaining and the State (Cambridge, 1985), pp. 55-6. The civil servants at the Ministry of Munitions had, in fact, been toying with the possibility of framing a few technical amendments to the Act. The situation on Clydeside caused them to address the prospect of radical changes. For the technical proposals, see Public Record Office (PRO) MUN 5/20/221.1/40, "Munitions of War Act 1915 - Amending Bill", by J.C. Miles, November 17, 1915; Official History of the Ministry of Munitions (OHMM), Vol. IV, Part II (London, 1920-24), p. 67.

7 Such disadvantages contrast with the favourable situation of the "moral entrepreneur" who, according to Becker, is able to mobilize a reform campaign. He takes, as his example, the United States Federal Board of Narcotics which sought to prohibit marihuana smoking in the 1930s. The Board, possessing abundant resources, adequate organisation and acceptability, was able to stimulate public interest in its campaign by arranging for the publication in newspapers of exaggerated and lurid accounts of the dire consequences of marihuana abuse, thus generating publicity which served to magnify the extent of the alleged evil. Thus, following lax enforcement of, or even indifference to, local laws prohibiting marihuana smoking, the Board eventually undertook the administrative responsibility for a federal law, in fact, a penal taxation measure, to curb the practice. What began initially as a bureaucratic enterprise - the Board "perceived an area of wrongdoing that properly belonged in their jurisdiction and moved to put it there" - was transformed into a "problem" of public concern by means of the preaching of a general value underpinning the campaign. This was the value, carefully stressed in the publicity campaign, of "self-control" and the elimination of "illicit pleasure" (the state of ecstasy induced by marihuana). Becker also notes that while the "natural history" of a rule tends to "follow the sequence from general value through specific rule to particular act of enforcement", the sequence could be changed. Thus, a "rule may be drawn up simply to serve someone's special interest and a rationale for it later found in some general value." For all these points, see Howard Becker, Outsiders (New York, 1972), pp. 133-8. As we shall see, the enactment of the Munitions Amendment Act in January 1916 also followed the emergence of a general legitimating value which transcended special interest pleading.

${ }^{8}$ See, for example, Branko Pribicevic, The Shop Stewards' Movement and Workers' Control, 1910-1922 (Oxford, 1959), pp. 45-8; Nation, October 16, 1915, pp. 109-111 (Cole); ibid., December 18, 1915, p. 442 (Mellor); J.M. Winter, Socialism and the Challenge of War (London, 1974), p. 136. 
stitution within that social formation, the Amalgamated Society of Engineers (ASE), could on its own, extract more government promises of reform following a meeting with Lloyd George on December 31, 1915, than did a representative conference of 55 trade unions which had been addressed by the Minister of Munitions a month previously on the criticisms surrounding the operation of the statute.

Thus, it is suggested that only an explanatory framework which recognizes the interaction of 'ideas, movements and events' can adequately account for the emergence of the amending statute. Within that narrative, we will observe in particular the broadening of the constituency demanding reform. From narrow, sectional politicized groupings demanding changes, the coteries expanded to embrace a wider range of interests beyond the designated boundaries of the labour movement. At the same time, there emerged a new legitimating value in the campaign. Instead of proving harmful to a distinct class interest, the Munitions Act was now alleged to be harmful to the national interest.

From its inception, the Munitions Act attracted fierce criticism from socialists of varying hues. The Labour newspaper, the Herald,${ }^{9}$ warned that in 'controlled' establishments where the new statutory disciplinary code was to operate, all trade union rules were to "go by the board, apparently at the mere request of the boss", and anyone refusing to do as he was ordered was to be fined. It went on to remind its readers that if trade unionists suggested that certain rules or practices should be retained (it presumably had in mind such features as demarcation lines or manning quotas), they would incur penalties of up to $£ 50$. Compulsory arbitration, for which it claimed no case had been made out, was, moreover, "here to stay". Nor would this "Workers' Slavery Bill", in the borrowed phrase of Robert Smillie, the miners' leader, speed up production 'one whit'. For it would only cause strife and bitterness, and thereby hinder rather than facilitate the supply of arms to the military.

The same issue of the newspaper also noted the view expressed in the Guild Socialist newspaper, the New Age, which had singled out the scheme of 'war munitions volunteers' as posing the gravest threat to organized labour. For the prospective supply of contingents of blackleg labour available to uncontrolled establishments ensured that profiteers would reap the benefit. The Herald's concern over the volunteer scheme was not, however, confined to the dangers of profiteering. For it also argued that even trade ${ }^{9}$ Herald, July 3, 1915. 
unionists who became volunteers could no longer rely on the strength of their organizations to protect them against despotic management. Thus divine intervention was sought.

Heaven help them! They are to be delivered over to a tribunal on which the Trade Union is not represented, and are to be forced to carry out any and every order [. . . . [They will] no longer be Trade Unionists but industrial soldiers subject to law and to commands. Discipline, instead of being in the hands of the unions, will be in the hands of the employers and employer's court. ${ }^{10}$

Hinting at a more theoretical critique, G.D.H. Cole concluded that the Act was $a,{ }^{11}$

[. . .] highly dangerous measure, and nonetheless dangerous because Mr. Lloyd George succeeded in persuading many of the trade union leaders to accept it.

Thus the "rout of the Labour forces" would ironically be accomplished with the aid and succour of most of the trade union leadership themselves. In this, Cole perhaps saw that class collaboration threatened to render trade unions an endangered species, a view endorsed by only a minority of trade unionists and labour journalists before the deluge of tribunal prosecutions and controversial workshop changes prompted second thoughts among the unsuspecting craftsmen and their leaders.

During this highly speculative period immediately following the passage of the Act, there were also uncompromising demands calling for direct action. For example, a body called the Trade Union Rights Committee (TURC), established in London on July 12, issued a manifesto designed to mobilize support against all coercive legislation and to organize a struggle within the trade unions to regain what it described as their "lost rights and freedoms". ${ }^{12}$ Yet its call for the defence and consolidation of trade unions together with the restoration of their rights and resistance to further capitalist encroachments was long on rhetoric and short on practicalities. Predictably vilified in the patriotic press and rebuffed by trade union leaders such as J.S. Brownlie of the ASE and Harry Gosling of the Watermen's Union, ${ }^{13}$ its blatant appeal for strike action against the Munitions Act was not shared by fellow critics of the legislation. Thus, as the Herald commented,

\footnotetext{
10 Ibid.

11 G.D.H. Cole, Labour in Wartime (London, 1915), pp. 214-5.

12 Cotton Factory Times, August 6, 1915, for contents of the manifesto. According to the Trade Unionist, January 1916, 20,000 copies were printed and issued.

${ }^{13}$ See the Herald, August 14,21, 1915 for these points. For the response of the TURC, see the Seaman, August 27, 1915; Nation, August 21, 1915, p. 678.
} 
To talk as some are doing, about a general strike against the Munitions Act, is very heroic, but unfortunately very foolish. Why should we disguise for ourselves the fact that never before was Labour so divided, so impotent and so content to let the future go hang? $?^{14}$

A general strike, it asserted, would only end in disaster (in fact the hugely successful South Wales miners' strike was only a few days off) ${ }^{15}$ In its place, Labour had to "wake up" and be more "practical", and see whether "something cannot be done with the existing machinery". ${ }^{16}$

Thus an avowedly propagandist body such as the Trade Union Rights Committee represented the negative, rejectionist strand of opposition to the Act. As such it was doomed to irrelevance, being grounded neither in practical politics nor in practical industrialism. ${ }^{17}$

The Herald's call for a more constructive alternative during the very early days of the Act was, however, taken up in the following week's issue of the newspaper by Cole and Mellor, the latter, ironically, a signatory to the manifesto of the TURC. ${ }^{18}$ Under the headline "Trade Unionism Dead?", 19 they asked whether nothing could be salvaged from the wreckage caused by Lloyd George's "confidence trick". The union leaders, they suggested, had meekly succumbed to capitalist aggression, receiving nothing in return. Instead, trade unionists faced a gloomy future of speed-ups

${ }^{14}$ Herald, July 10, 1915. Clearly, the TURC as an organization could not have been responsible for such a call, given that it was only established a few days after the Herald's remarks.

${ }^{15}$ Following the breakdown of wage negotiations, and despite the intervention of Lloyd George and other government ministers, the South Wales miners resolved on industrial action. In the hope of pre-empting the strike, Lloyd George extended the recently enacted Munitions Act to the coal industry, and posted notices in the district, advising of the statutory prohibition on industrial action. The move had the opposite effect, for, the following day, 200,000 South Wales miners stopped work. The newly-appointed munitions tribunal chairman pointed out the futility of mass prosecutions to Lloyd George, who then exerted more pressure on the coal owners. A settlement, without any prosecutions, was reached within a few days. See Wrigley, op. cit., pp. 122-8.

${ }^{16}$ Herald, July 10, 1915. See also similar remarks in G.D.H. Cole and W. Mellor, "Labour After the War: Preparation is Half the Battle", Trade Union Worker, March 1916, pp. 9-10.

${ }^{17}$ It is difficult, therefore, to see the force of the argument that there existed a close affinity between the TURC and the, surely more effective and lasting, Clydeside shop stewards' organization, the Clyde Workers' Committee. For this view, see R.M. Drislane, "Trade Union Leaders and Politics, 1910-1922", London University Ph. D. (1975), p. 151. A number of trades councils did lend their support to the TURC but to no effect. See Alan Clinton, The Trade Union Rank and File: Trades Councils in Britain, 19001940 (Manchester, 1976), p. 121.

18 Other prominent signatories from the wartime rank-and-file movement included Tom Quelch and W.F. Watson.

19 Herald, July 17, 1915. 
through the rapid Americanization of production, as well as a mobile army of blacklegs and a system of fines deducted by employers from wages. Since the main battle against the Act was lost, the union rank-and-file were urged to press for the reorganization of trade unionism itself.

Out of chaos may come a new birth. The old unionism was not so marvellous a product that we cannot dream of something better to take its place. Onlyit is up to us. ${ }^{20}$

Here, Cole and Mellor perhaps had in mind the experiment of the NorthEast Coast Armaments Committee. This was a council of employers and trade unionists, entrusted with wide if somewhat undefined powers jointly to administer munitions production in the area on a representative basis from April 1915 until wound up by Lloyd George about 3 months later.$^{21}$ As a rudimentary, embryonic and shortlived foretaste of what Guild Socialism might offer, the experiment undoubtedly inspired, in the wake of criticisms of the Munitions Act, the reform proposals for local joint committees to replace legal compulsion, to which even the union leadership became converted in the last quarter of 1915. At least, in the absence of a solid foundation of empirical data illustrating the working of the Munitions Act in fact and not in theory, the prescription for joint control offered a reform perspective that on the basis of precedent was not wholly unrealistic. To this extent, early evidence for the 'idealist' influence on the emergence of the Amendment Act can be identified.

In the event, the alarm signals from the workshops and shipyards were now beginning to ring. The anxieties expressed over the gloomy prospects facing munitions workers were now starting to give way to bitter complaint, and the sudden inroads on munitions workers' freedoms became live issues. The 'pressure of events' would soon, in its turn, give birth to a mass mobilization aimed at curbing the worst excesses of the Act's coercive powers.

The pages of the engineering union's monthly journal testify to the dramatic changes in working conditions inaugurated by the Munitions Act. From Manchester, for example, the ASE district delegate, Joseph Binns, noted that by August $1915,^{22}$

20 Ibid.

${ }^{21}$ G.D.H. Cole, Workshop Organisation (Oxford, 1923), p. 89; ibid., Trade Unionism and Munitions (Oxford, 1923), p. 124.

22 ASE, Monthly Journal and Report, September 1915, p. 23. 
The Munitions Tribunals are now in full swing. The activities of several firms in this area to take every advantage of the provisions of the Act are specially noticeable. Our members ought to be equally active and ensure that the application is equitable by insisting upon the firms also complying with clauses relative to changes, etc. [. . .] our members would be well advised (1) to object to any changes being introduced "as to rates of wages, hours of work, or otherwise as to terms and conditions of, or affecting employment, etc.", unless the statutory notice has been given to the recognized authorities and opportunities have been given to discuss such changes; (2) we should also refrain from leaving off work, protest to the firm against unfair impositions and then formulate a charge for the tribunal to consider and place the employer as defendant.

From Sheffield, it was reported that the men were "indignant" at the arbitrary rules posted up in the workshops, and which intimated that fines would be imposed for lost time and for other offences. There had been the "greatest difficulty" in dissuading the members from downing tools until an opportunity for consulting with the employers had been granted. Moreover, the district delegate, Arthur Shaw, concluded that after,

[. . .] considering the strenuous efforts and the abnormal hours the men are working, the posting of notices is looked upon as an insult to their intelligence, and is bitterly resented. ${ }^{23}$

The West Country official of the ASE, W.H. Miller, whose members were confronted with a number of prosecutions by employers, advised that, ${ }^{24}$

In my opinion, it will be wise for our members to keep to the practices in existence before the war for the settlement of differences arising in the workshops, and make this new Act thereby a dead letter.

Two months later he reported that his experience of the tribunals during this period merely, ${ }^{25}$

[. . . ] confirms the policy that I have advocated, where possible, that we should keep away from them as much as possible.

Of course, the problem was that the new works rules and tribunals would not simply go away. Thus, whether the advice to members was to test every management step against the small-print of the Act, or to demand insistence upon the status quo ante and to pretend that the Act never existed, the matter of statutory implementation was beyond the control of the unions and their members, as events in Liverpool, for example, dramatically showed.

23 Ibid., p. 25

24 Ibid., p. 33.

25 Ibid., November 1915, p. 60. 
From there, the local ASE district delegate, R.O. Jones, reported to his members in September 1915, that, ${ }^{26}$

As matters stand, workmen are being dragooned into doing things, whilst the employer can chop and change according to the state of his liver. Trade Unionists have been requested to give up many things; it would be a pleasure to find some employers giving up their dirty methods. The sacrifices are being extracted all from the worker's side.

Among the major employers in the district, the legal opportunities were being eagerly exploited by Cammell Laird shipyard at Birkenhead. The firm had refused to pay a 4/- advance agreed for the district, provoking its workers to reply with a widespread ban on overtime. The company then responded by posting yard disciplinary rules which indicated their intention to impose fines for loitering and for similar offences. Such provocative action drew strong condemnation from the local ASE official whose combative attitude had scarcely been disguised. As he reported, ${ }^{27}$

One can imagine the illimitable interpretation that can be placed upon a term of that description, particularly to an imaginative mind. That the whole business is both fatuous and silly time will tell.

That time was not long in arriving. First, half a dozen employees of the shipyard, having refused to work overtime, were fined $£ 1$ each, and assured the tribunal that they would in future work a reasonable amount if required. ${ }^{28} \mathrm{~A}$ few days later, 22 engine fitters employed at the yard also received the same sentence. Indeed, that very day, the company had embarked upon the prosecution of another 245 men, having been urged to do so by the Ministry of Munitions on the ground that, as explained by the firm, "Men of a certain type would never realise the war without a prosecution [sic]". ${ }^{29}$ Though these particular summonses were in fact withdrawn on the men's promise to comply with overtime instructions, ${ }^{30}$ yet another 69 summonses for persistently losing time were heard a week later against platers, drillers, angle-smiths and apprentices employed at the yard. ${ }^{31}$

${ }^{26}$ Ibid., September 1915, p. 21.

${ }^{27}$ Ibid.

${ }^{28}$ Glasgow Herald, September 6, 1915.

${ }^{29}$ Ibid., September 10, 1915.

${ }^{30}$ The commitment seems to have been made on behalf of the men by a delegation of union officials including Jones, which appeared to concede that the men's action in refusing overtime was unjustifiable. It is not clear whether in fact the men had been consulted first before the promise was made. If not, then either Jones' rhetoric was hollow or his condemnation of the men's action was intended to pacify the company and tribunal. Subsequent events suggest that the men interpreted the officials' action as a sell-out. See ASE, Monthly Journal and Report, October 1915, p. 29; Engineer, October 29,1915 .

${ }^{31}$ Glasgow Herald, September 20, 1915. 
Except in cases where medical certificates were produced, fines ranging from $5 /$ - to $£ 3$ were imposed.

The proceedings led to ${ }^{32}$

[. . . ] a scene of indescribable uproar at the close. Men leapt to their feet, shouting denunciation of the firm, and of some of their officials, one man declaring that the case was causing a revolution in the country by its finding, another shouting, 'It is time the Germans were here if this is how British working men are to be treated. We are here, not as slaves, but as workmen, and we can do our work.'

It is suggested that these protests were not a radical attack on the Munitions Act mounted on class lines. Rather, the sense of the complaints by the men disclosed a broader critique of the Act based on the danger posed to a wider national interest by an insensitive application and perversion of a public measure for private gain. The terms of debate on Merseyside were, in fact, a pointer to the unfolding 'pattern of events', principally on Clydeside,${ }^{33}$ in which the claims of universalism coalesced in a broad 'movement' to transcend the appeal of particularism.

Whatever political lessons might therefore be drawn from the passing of the Munitions Act, its industrial effects were now being readily felt. They were, most obviously, the inauguration of works rules permitting employ-

32 Ibid.

${ }^{33}$ The following major tribunal clashes in the first few months, apart from the Liverpool incident and cases in Glasgow, may be mentioned: (1) a subsequently withdrawn prosecution of 28 strikers at Vickers, Barrow in July. See (PRO) MUN 5/353/349/1, "History of Labour Regulation Department, by Miss C.V. Butler, February 1917"; (2) fines imposed on 31 Manchester strikers in the same month. See Woman's Dreadnought, August 7, 1915, p. 295; ASE, Monthly Journal and Report, August 1915, p. 32; (3) the dismissal, without leaving certificates, of over 100 armour-plate workers at the Manchester works of Armstrong Whitworth in August. See the Nation, September 4, 1915, p. 735; Glasgow Herald, September 4, 1915. The irony of John Hodge's Steel Smelters' Union apparently sanctioning a strike in response to the dismissals was not lost on the Forward, the Glasgow socialist newspaper, which noted Hodge's previous declarations that any strikes at the time were "inconceivable and unthinkable". See the Forward, September 11, 1915; (4) the prosecution of 50 boilermakers from Thorneycroft's shipyard in Southampton. See, inter alia, Lord Askwith, Industrial Problems and Disputes (London, 1920), pp. 396-8; (5) a succession of mass prosecutions for striking and for allegedly breaking yard rules in Tyneside shipyards, together with multiple leaving certificate applications. See Glasgow Herald, September 9, 27, 29, October 20, November 25, 1915; R. v Newcastle Munitions Tribunal, ex parte Lloyd George, Law Journal, Vol. 50, 1915, p. 530; (6) extensive unrest leading to tribunal hearings at Robb, Caledon shipyard at Dundee. See Glasgow Herald, October 1, 16, 1915; Scottish Record Office (SRO) HH31/22, "Memorandum as to the Prosecution of Certain Workmen in the Employ of the Caledon Shipbuilding and Engineering Company, Dundee"; (PRO) MUN 5/80/341/3, "Clyde Munitions Workers: Minutes of Evidence", pp. 151-6, 271-6; also (PRO) TV/132/1, "Treasury Out-Letters to Ministry of Munitions" and (PRO) MUN $5 / 97 / 349 / 10$, "Treasury Correspondence re Fines Imposed by the Munitions Tribunals, December 8, 1915, and February 11, 1916". 
ers to harry and harass their employees. As the ASE delegate for NorthEast England, James Ratcliffe, reported, ${ }^{34}$

The novelty of the business, however, is in the fines imposed for lost time, disobeying orders, quarrelling and a general want of decorum - all essentials as it seems, in the acceleration of the output.

For the New Statesman, the challenge to labour was not merely the employers' desire to reorganize their factories. It was, additionally, the realisation that both trade union leadership and workmen generally were 'usually even pathetically willing' to give up trade customs where it was suggested they were harming the national interest. Thus it warned that, ${ }^{35}$

What causes trouble is the assumption on which employers (and, we fear, also the Munitions Department) are acting, that it is for the employers arbitrarily to impose new rules and for the workmen simply to obey [...]. Here's 'Industrial Junkerdom' with a vengeance!

This was the crux of the matter. Labour discipline might be tolerated by the majority of the rank-and-file if essential to the war effort and if comparable sacrifices were made by employers. Instead, employers were seen to be feathering their own nests, while the posting of new disciplinary rules without prior consultation with the men was bound to cause resentment. Thus the grasping of the opportunity by employers to enforce the new disciplinary rules was perceived as a shameless exploitation of the Act. For though disciplinary fines had been a feature of a number of trades such as shopkeeping, mining, textiles and shipping prior to the war, ${ }^{36}$

They were merely a heterogeneous set of orders, dealing in detail with small points of workshop practice, many accidental, some obsolete. Ostensibly they were enforced by fines, suspension or dismissal, but in reality they were frequently in abeyance [. . . ]. Discipline [ . . . ] rested on personal authority and unwritten sanctions. ${ }^{37}$

Their sudden revival, and moreover, added potency, thus signalled an end, in many works, to the "indulgency pattern" ${ }^{38}$ hitherto prevailing. The assistant general-secretary at the Ministry of Munitions, William Beveridge, had indeed reported on August 12, 1915, that "hundreds" of firms

${ }^{34}$ ASE, Monthly Journal and Report, September 1915, p. 22.

${ }^{35}$ New Statesman, August 7, 1915, p. 411.

36 Ibid., November 13, 1915. Also David Sugarman, J.N.J. Palmer and G.R. Rubin, "Crime, Law and Authority in Nineteenth Century Britain", Middlesex Polytechnic History Journal, Vol. 1, Spring-Autumn 1982, pp. 111-15.

${ }_{37}$ Humbert Wolfe, Labour Supply and Regulation (Oxford, 1923), p. 175.

38 Alvin Gouldner, Patterns of Industrial Bureaucracy (Glencoe, 1954) for the use of this term. 
had already posted up new rules under the authority of the Act. ${ }^{39}$ Thus it was not only the abrogation of the right to strike or the restriction on labour mobility or even the lifting of craft protections that constituted a grave challenge to workmen's liberty. It was the prospect of prosecution for petty offences that seemed to pose an immediate threat to millions of munitions workers, craftsmen or unskilled. For as G.D.H. Cole pointed out, ${ }^{40}$

Unless the workman is as docile as the most down-trodden of slaves, and at the same time as efficient as the best of his class, the tribunal is waiting to receive his money.

Moreover, as the activities of Cammell Laird appeared to suggest to trade unionists, prosecutions might be undertaken for reasons other than the mere punishing of instances of worker misconduct. For Cammell Laird had clearly decided that the use of the tribunal would further its own wage policy of resistance to the district settlement. Thus the tribunal, far from being a neutral adjudicator in the 'national interest', appeared to have been 'captured' by a major employer for the ulterior purpose of entrenching that resistance and of legitimating the company's stance. Thenceforth, the rising toll of tribunal statistics was matched by the rising torrent of trade unionists' complaints, and by demands that the 'national interest', as an emergent property, be protected.

Thus, W.F. Watson, in the ASE journal's correspondence columns, drew attention to the contrast between the defence of the Munitions Act, as expressed by the committee of trade union leaders chaired by Arthur Henderson, which 'advised' Lloyd George on labour matters in the munitions trades, and the experiences reported by the ASE district delegates. Whereas the committee, the National Advisory Committee on Labour Output (NAC), had insisted that provisions in the Munitions Act (i.e. the provisions on the restoration of pre-war practices) ensured that employers, after the war, would be prevented from exploiting the abnormal wartime conditions in the workshops, Watson complained that, ${ }^{41}$

[. . . ] this month's Journal ${ }^{42}$ tells a very different tale. Ten out of the twelve organizers tell us in their reports of the trouble they are having arising out of this same Munitions Act. The employers, they tell us, are using this precious Act to prevent workers leaving their jobs, that workers are being fined for losing time, that women and unskilled workers are being used to cheapen production. . .

${ }^{39}$ (PRO) MUN 5/48/300/9, "Meeting with Shipbuilding Employers' Federation, August $12,1915^{\prime \prime}$.

${ }^{40}$ Nation, November 20, 1915, p. 289.

${ }^{41}$ ASE, Monthly Journal and Report, December 1915, p. 94. See also the general observations of another correspondent in ibid., October 1915, pp. 76-7.

${ }^{42}$ That is, presumably in the November issue. 
It was, especially, the last factor which appeared to many to pose a threat to the long-term future of the craftsmen. Thus mixing polemic with genuine fear for the future, Watson later charged the NAC with, ${ }^{43}$

[. . . blindly assisting the employers and Government to use the international crisis as an excuse for breaking the power of organized labour.

Another critic, Fred Jowett, the Independent Labour Party (ILP) member of Parliament for Bradford, voiced his objections in the columns of Land and Water.$^{44} \mathrm{He}$ drew particular attention to the power of employers to prevent workers moving elsewhere whilst the latter were simultaneously deprived of a full quota of work. Thus, if men wished to change jobs in order to obtain the trade union rate, they were, he claimed, prosecuted. Moreover, the toleration of low pay and of long hours by tribunals refusing leaving certificates meant that, under the Act, men were as firmly fixed to the service of one employer as if they had been branded as serfs (a sentiment often encountered among critics of the Act) ${ }^{45}$ Finally, he complained, those rules and customs which had guaranteed relatively high rates for certain operations were being steadily and quietly set aside; changes in working practices were not being recorded, and the government were taking no action to remedy the defect. ${ }^{46}$

Jowett's local trades council in Bradford called for the repeal of the Munitions Act as a "gross interference with the rights of the workers". ${ }^{47}$ Particular exception was taken to the power of the employer to discharge at will, while the workmen had the right to leave taken away from them by virtue of the operation of the leaving certificate scheme. The proposer of the motion at the trades council drew attention to the case of a labourer who had left his employment at the Lancashire and Yorkshire Railway in order to take up a post in a dye-house at $5 /$ - a week more. Since he did not have a leaving certificate, the railway company were entitled to demand his discharge from his new employer. This was done, but the labourer was not re-employed by the railway company and as a result, was still unemployed after three weeks.

${ }^{43}$ Trade Unionist, April 1916, p. 3.

${ }^{44}$ Land and Water, October 2, 1915, pp. 18-19.

${ }^{45}$ Cf., the Clydeside shop stewards' convenor, David Kirkwood's remark to Lloyd George that, "I am as much a slave to Sir William Beardmore (his employer) as if I had the letter 'B' branded on my brow'. See David Lloyd George, War Memoirs, Vol. 1 (London, 1933), p. 314.

${ }^{46}$ For a general response to Jowett's charges, see Lord Sydenham's reply in Land and Water, October 9, 1915.

47 Yorkshire Factory Times, October 28, 1915. According to Clinton, op. cit., p. 75, the Munitions Act was constantly being discussed by trades councils, and protests increasingly grew strident as the war wore on. 
It was a scandal that men were kept idle in that way whilst machinery all over the country was standing for want of labour,

complained the proposer of the motion. ${ }^{48}$

The descriptive imagery employed to depict the effects of the Act testifies to the intensity of hostility which it was engendering. Thus it was said that the Act furthered the objectives of private employers in their endeavour to "make human beings into a machine", ${ }^{49}$ and that it was intended to "reduce their workmen to slaves", ${ }^{50}$ and that the aim was to "secure a labour force as docile and responsive as if it was made up of horses". ${ }^{51}$ What some expressions of opinion implied was that the Act was a mere pretext, and that, ${ }^{52}$

[. . . ] the governing class is using the opportunity of the War to alter the institutions of the country so that any kind of resistance against industrial oppression can be put down.

Indeed, that the government might be suspected by the unions of acting as the 'mouthpiece' of the employer was even admitted by the leading Ministry of Munitions official, Sir Hubert Llewellyn Smith, despite his own resolve to act according to the dictates of the 'national interest'. ${ }^{53}$

The criticisms expressed above were of two kinds. First, were the views of those who repudiated the very principle of the Act, such as Arthur MacManus, a Clyde shop steward and editor of the Socialist ${ }^{54}$ the newspaper of the Socialist Labour Party. Second were the understandable complaints of those munitions workers and their union officials who were at the sharp end of the disciplinary process. However, another strand of the debate sought to engage in constructive criticism while acknowledging the urgency of the situation. The Clarion, ${ }^{55}$ edited by Robert Blatchford, appeared to accept

48 Yorkshire Factory Times, October 28, 1915.

49 ASE, Monthly Journal and Report, January 1917, p. 27. The date of this comment lends support to Clinton's remark (supra).

50 Ibid., November 1915, p. 57.

51 New Statesman, December 4, 1915, p. 197.

52 Cited in Roger Davidson, "Government Labour Policy, 1914-1916: A Reappraisal”, Journal of the Scottish Labour History Society, No 8, June 1974, p. 3.

53 Ibid., 8, pp. 13-14.

${ }^{54}$ Socialist, January 1916, p. 32. This was, of course, the view of the Clyde Workers' Committee. McManus later became the leader of the newly-founded British Communist Party. The forged Zinoviev letter of 1924 contained his (equally forged) signature as a "witness" to the letter.

55 Clarion, November 26, 1915. 
the rationale for the measure (in an item entitled "The Munitions Bumble"), though it had earlier been savage in its condemnation of the administrative chaos which the Act was failing to remedy. Thus it had complained that, ${ }^{56}$

Some of the things which the Munitions Department have done tend to decrease rather than increase the output of the workers. Do such things as the following help towards harmonious working: the establishment of munitions tribunals presided over by men whom trade unionists distrust? Is it a good thing to send a list of offences and their penalties to be posted up at Government-controlled firms? Another arrangement, the appointment of $\mathrm{men}^{57}$ to enter firms at all hours and prosecute so-called slackers without any appeal to the foreman? [ . . ] Calling the workers slackers and punishing them will not explain why thousands of shells are delayed from the first, because of the rolling mills being unable to supply bar steel fast enough; thousands of shells waiting for nose bushes before they can be completed; shells waiting the results of the firing tests from the Government departments; work held up by the grocers, tailors, shop assistants, labourers who are appointed by a Government department to examine shells that have previously been examined by skilled mechanics..$^{58}[\ldots]$ For the benefit of organisation, the solicitor must retire for the engineer!

In a separate contribution, the Clarion journalist, R.B. Suthers, ${ }^{59}$ drew attention to the 'maladroit' working of the Act, by questioning why the Minister of Munitions persisted in appointing as tribunal chairmen those who were not trusted by munitions workers.$^{60}$ If there was slacking in the workshops, then the only solution was to place the shops under the control of the men and let them deal with the slackers themselves. It was because employers "indulge in "petty tyrannies"" and because the men suspected the motives of the employers in instituting "unnecessary" disciplinary measures, that munitions workers resorted to slacking.

The theme of salvaging the Act from the morass of suspicion and in-

56 Ibid., September 17, 1915.

57 These were presumably the ministry's labour officers.

58 There was widespread criticism of the competence of inspectors. See a Commons amendment proposed by W.T. Wilson of the Amalgamated Society of Carpenters and Joiners that inspectors be "properly and technically qualified". This was resisted by Christopher Addison, the Parliamentary Secretary to the Minister of Munitions, despite the allegation that pawnbrokers' assistants, labourers and butchers had been appointed to these posts. They were the "laughing stock" of the men and of the foremen. One instance was cited by Wilson where an inspector had rejected 78 out of 84 shells while another had passed 74 of them. See Amalgamated Society of Carpenters and Joiners, Journal, January 1916, p. 45.

${ }_{59}$ In 1909 , he published the pragmatically entitled Common Objections to Socialism Answered.

${ }^{60}$ Clarion, October 8, 1915. 
vective in which it had been placed by thoughtless managerial opportunism was one similarly pursued by the New Statesman. While unconvinced, unlike the Clarion, of the initial justification for the Munitions Act, the New Statesman, in a major article entitled "The Failure of the Munitions Act", ${ }^{61}$ made its observations on the footing that the wholesale repeal of the measure, which it would have favoured, was not now politically practicable. The Act, it insisted, was, after four months, a blunder and a failure. While munitions output had undoubtedly increased during this period, that result could be explained simply by Lloyd George's "extraordinarily lavish outlay of capital" and by the enlargement of, and increase in, the number of munitions factories. None of these developments depended, in fact, on the Munitions Act itself. Yet the working of the Act had produced a state of mind on the part of munitions workers which had resulted in a widespread sullen resentment against a measure which they considered was being harshly administered exclusively in the interests of employers. It continued, ${ }^{62}$

Now we put it to Mr. Lloyd George very seriously that this kind of things will not do. The Munitions Act was, in our judgment, bad from its inception. If we want the British workmen to increase their output we must not try to do it by coercion. If we wish to get additional workers into munitions factories, it is the very worst way to subject these factories to exceptional penal conditions from which other employments are free. But having got the Act, it is vital to see that it is administered, not only fairly and impartially, but also in such a way as to seem fair and impartial. To let employers and foremen use the Act to compel the workers - especially the women - to accept whatever rates of pay the employer chooses (the workers are reminded that it is an offence for them to refuse the job, and that they are not allowed to leave); to coerce men and women, doing sixty to seventy hours a week, to work overtime, and fine them if they refuse; to retain by force men or women who quite legitimately wish, on the expiry of their contracts of service, to change their situations on all sorts of personal grounds; to give the employer power to make, and to enforce by fines and "suspensions" any rules he pleases, without asking the workmen's consent - all this is steadily to augment the resentment of the wage-earning class. If it is continued, it will do more to make them "tired of the war" than any amount of "pacifist" propaganda. It is not by a Munitions Act that M. Albert Thomas ${ }^{63}$ has got such splendid results from the French workmen. We shall never extract a maximum output out of sullen and angry workers who feel themselves enslaved, and, as we must add, who believe themselves to have been tricked and defrauded.

61 New Statesman, November 13, 1915, pp. 124-5.

62 Ibid., p. 125.

63 The French minister of munitions. 
Thus the approach of the New Statesman (which also reflected the attitudes both of the Herald (supra) and of the ILP politician, W.C. Anderson, in his series of articles for the Glasgow Socialist newspaper, the Forward $)^{64}$ was, albeit reluctantly, to offer constructive criticism as to how matters might be improved within the statutory regime. ${ }^{65}$ Even The Times ${ }^{66}$ was disposed to recognize that a measure which was "bound by its very nature to cause some friction", could authorize a "grievous act of oppression and an intolerable curtailment of personal liberty". Yet it would be folly, it insisted, to offer concessions which would only encourage hostile elements such as the Independent Labour Party. ${ }^{67}$

But the apparent success of the campaign to persuade the Minister of Munitions, Lloyd George, to reconsider the Munitions Act owed much to the manner in which the potential beneficiary of reform was now claimed to be the nation itself and not merely the interests of labour. As the Clarion, looking in anticipation at changes in the Act, commented, ${ }^{68}$

Petty tyrannies and wrongs have accumulated so extensively under the Munitions Act that the promised Amending Bill had [sic] become quite as essential to the national welfare as the original Act.

Thus, the struggle to appropriate the legitimating value of the 'national interest', that magically hypnotic appeal which reduced even Cammell Laird recalcitrants to protestations of loyalty, now informed the contours of the debate.

What is clear, therefore, is that the campaign for reform (or for repeal)

${ }^{64}$ Forward, September 18, 25, October 2, 9, 1915.

${ }^{65}$ To the extent that ideological objections to war were shared by the New Statesman, they did not explicitly inform its criticism of the Munitions Act. In this respect, its editorial approach differed from that of other socialist publications, such as the Labour Leader, the banner of the I.L.P.

${ }^{66}$ The Times, November $1,1915$.

${ }^{67}$ At its 1916 conference, the ILP was to approve a resolution calling for the "unconditional repeal of the Munitions Act, recognising that no amendment of the same can be effective while the principle of the Act remains the same and the control of munitions is vested in the hands of private ownership upon a basis of profit". See ILP, Annual Conference Report 1916, p. 45. The Labour Party, by contrast, had merely demanded the "most drastic amendments" to the Act. See Labour Party, Report of Fifteenth Annual Conference, Bristol, 1916, p. 128. While the party was active in parliamentary discussions on the munitions legislation, the executive committee of the party was rather more subdued and scarcely gave any consideration to it at its regular meetings, as the absence of reference to this question in the executive minutes seems to suggest. But see R.M. Martin, TUC: The Growth of a Pressure Group, 1868-1976 (Oxford, 1980), p. 132. Martin argues for a leading role for the party in forcing a relation of "close dealing and hard bargaining" between the government and the unions. However, even if the assessment related exclusively to the Labour Party in parliament, the ASE, surely, possessed greater influence.

${ }_{68}$ Clarion, November 26, 1915. 
was initially undirected and haphazard. Originally identified with 'extremists' and with militants, criticism of the Act gradually altered shape under the 'pressure of events' taking place in the workshops and in the tribunals. The government could, of course, discount, as the activities of a fringe minority, the prompt and inevitable accusation that the Munitions Act was an employers' charter and an attack on trade union rights and freedoms. However, when the critics began to invoke the 'national interest' as a justification for amendment and to remind the authorities that the Act was itself generating more unrest than it was designed to suppress, sensitive chords were touched within the Ministry of Munitions. Moreover, the revelations (or innuendoes) concerning employers' blatant abuses of the Act, which the tribunals seemed to be ratifying in their decisions, also drove the union leadership to recant their earlier extravagant praise for the measure. Thus, whilst opposition within the trade union movement to the Act remained limited to the supposed special pleading of an obdurate and unpatriotic minority, it presented no fundamental threat to government policy. Once, however, the trade union leadership began to absorb the lesson of rank and file discontent inspired by the latter's direct experience of the Munitions Act in the workshops and before the tribunals, the leadership had little choice but to respond to the barrage of complaints. The option of dismissing the critics as individuals "not altogether without ulterior motives", in the words of Alexander Wilkie, general secretary of the Shipwrights' Association, ${ }^{69}$ was no longer convincing once denunciations were expressed in the name of the 'national interest'.

The most influential factor in propelling the case for reform onto a 'respectable' platform was, however, the report of the Balfour-Macassey Commission set up by Lloyd George to "enquire into the causes and circumstances of the apprehended differences affecting munition workers in the Clyde district". ${ }^{70}$ Its sober criticism of the methods employed by local employers to enforce the leaving certificate scheme on Clydeside $;^{71}$ its acknowledgement that the Act was creating added tension between foremen and workers, as the authority of the foremen was now underpinned by penal sanctions; that there was widespread disruption to existing payment systems; that jealousy had been created by the arrival of more favourably treated newcomers from Canada and the United States; and that the

69 SSA, Quarterly Report, July-September 1915, p. 5.

${ }^{70}$ Clyde Munition Workers, Report of the Rt Hon. Lord Balfour of Burleigh and Mr Lynden Macassey, K.C., Cd. 8136, 1915.

${ }^{71}$ The most comprehensive analysis of the report's investigation into the leaving certificate scheme is in Alastair Reid, "The Division of Labour in the British Shipbuilding Industry, 1880-1920”, Cambridge Ph.D., 1980, esp. pp. 342-9. 
imprisonment of the shipwrights following the Fairfield episode ${ }^{72}$ had had disastrous consequences, served to confirm the legitimacy of the reform campaign. A government commission of enquiry whose credentials could scarcely be impugned by the authorities had, in effect, now assumed the mantle previously worn by less respectable and publicly disapproved 'wrecking movements' such as the Trade Union Rights Committee and the critical labour press.

Such a vindication of the reformers' case, it might have been thought, could scarcely have been bettered. But once a number of employers, or those sympathetic to their interest, also questioned the value of the Act as then framed, the credibility and effectiveness of the reform campaign was apparently complete. Thus even the Engineer ${ }^{73}$, which represented the employers' viewpoint, accepted that the existence of munitions workers' grievances concerning the discipline imposed upon them by the Act was "not conducive to the best workmanship" and that some foremen and employers had taken advantage of the Act by summonsing their employees to the tribunals for trivial offences where "these bodies, not always cognisant with the facts" had issued harsh decisions. The recognition by nonlabour sources that defects existed, did, in fact, confirm the shift which had occurred in the nature of the demand for changes. From an unco-ordinated and erratic protest mounted on narrow, sectarian lines, and which reflected political prejudice as much as special pleading, the reform campaign had been transformed into a broad, institutionalized movement.

\section{IV}

It will be observed that the present paper has not sought to discuss in detail the principal watershed events predating the amending statute of January 1916, such as the imprisonment of the Fairfield shipwrights and the hearings of the Balfour-Macassey Commission in Glasgow. Reference has already been made to other authors who have documented these events at length. ${ }^{74}$ We would, however, interpret both the agitation for direct action to resist the Munitions Act in its original form, including the threat of a general strike on Clydeside if the Fairfield shipwrights were not released, and also the protracted negotiations over the details of the proposed statutory changes, in particular the major conferences between the trade union leaders and Lloyd George on November 30 and December $30-311915,{ }^{75}$ as central elements of a 'social movement' whose crystallization was a conse-

${ }^{72}$ See note 6.

${ }^{73}$ Engineer, December 17, 1915.

${ }^{74}$ Notes 6 and 71 , supra.

${ }^{75}$ See, especially, Wrigley, op. cit., pp. 144-8. 
quence of the 'pressure of events' in the workshops. ${ }^{76}$ Additionally, in order to give direction and credibility to the reform campaign, we must have regard to the influence exerted by a wide spectrum of ideas. These ranged from the obstructive, as represented by the Trade Union Rights Committee, via the alternative, such as the Guild Socialism of G.D.H. Cole, to the compatible (in the eyes of the government), as reflected in the views, perhaps inspired by corporatist tendencies, ${ }^{77}$ of those politicians, journalists and trade union.leaders who warned of the damage to the "national interest' if changes did not take place. ${ }^{78}$

Thus, in focusing upon certain processes of legal change, we have sought to integrate competing theories of legal innovation, whether through events, movements or ideas, into a comprehensive account in order to explain satisfactorily the growth of the reform campaign and the eventual emergence of an amending provision. In short, a pluralist interpretation, though one revolving round explanatory concepts, is to be preferred to a monolithic approach.

${ }^{76}$ In the case of those trade union officials both on Clydeside and nationally who had previously given fulsome support to the introduction of the Act, but who were now reluctantly converted to the reformist demand for amendment, it is suggested that their intentions were, in part, to restore their reputation for robust leadership among their membership. For their earlier support for the measure of July 1915, and their condemnation of dissent (note 4, supra) had now been shown to be a serious and embarrassing misjudgment. Thus the trade unions' reform campaign from October 1915 constituted, on the part of these officials, as much a symbolic quest to uplift both their self-esteem and their authority, as it did an effort to secure instrumental gains. In effect, a concern for their own leadership position prompted the officials to identify yet a further justification (apart from the national interest) for their about-turn. Thus the belated pursuit of "equality, equity and reciprocity", in the words of Alexander Wilkie of the Shipwrights", emerged as an integral feature of their campaign to lessen the iniquities of a statute which had recently received their imprimatur. For Wilkie, see SSA, Quarterly Report, October-December 1915, 80, quoting his speech in the Commons on January 4, 1916 [sic]. "Reciprocity" was identified by Lloyd George as a feature of trade union demands made at the conference of November 30. See Glasgow Herald, December 1, 1915. Perhaps one acute example of the shift in attitudes on the part of union officials is shown by the Fairfield Shipwrights' episode. There, the union's disapproval of the strikers had originally been "[ . . .] generally shared by the official representatives of the other unions. But the movement started by the rank and file soon overcame the resistance of their leaders". The latter no doubt reasoned that if they could not beat them, they might as well join them. See OHMM, Vol. IV, Part II, 54.

${ }^{77}$ For a defence of a corporatist perspective on the war economy, see Gerry R. Rubin, "Law, War and Economy: The Munitions Act 1915-17 and Corporatism in Context", Journal of Law and Society, Vol. 11, 1984, pp. 317-33.

78 Whether the concessions gained by the trade unions in the amendment statute of January 1916 were substantive may well be questioned, though they were no doubt hailed as a symbolic victory. For a consideration of the matter, see Gerry R. Rubin, "The Enforcement of the Munitions of War Acts 1915-1917, with special reference to Proceedings before the Munitions Tribunal in Glasgow, 1915-1921", Warwick University Ph.D. (1984), pp. 113-17. 